\title{
Investigation and Analysis on Current Situation of Coal-Burning Fluorosis Prevalence
}

\author{
Wei Yan, Jun Xie*, Xinshu Li, Yalin Chen, Wenli Huang, Shuang Zhou \\ Disease Control and Prevention Center of Chongqing City, Chongqing, China \\ Email: ayanwei@163.com, *82579314@qq.com
}

How to cite this paper: Yan, W., Xie, J., Li, X.S., Chen, Y.L., Huang, W.L. and Zhou, S. (2017) Investigation and Analysis on Current Situation of Coal-Burning Fluorosis Prevalence. Open Journal of Epidemiology, 7, 115-123.

https://doi.org/10.4236/ojepi.2017.72010

Received: March 17, 2017

Accepted: April 18, 2017

Published: April 21, 2017

Copyright $\odot 2017$ by authors and Scientific Research Publishing Inc. This work is licensed under the Creative Commons Attribution International License (CC BY 4.0).

http://creativecommons.org/licenses/by/4.0/

\begin{abstract}
Objective: The purpose of the paper is to provide the result from investigation on the current situation of coal-burning fluorosis prevalence in Chongqing City and make an assessment on the prevention and curing measures. Method: The Dean's Method is applied to investigate on the fluorotic teeth of locally-born children aged between 8 to 12; investigate how modified cooking stoves are utilized by households and how food maize and hot pepper are being dried; and test the urinary fluorine content and pepper fluorine content. Result: The investigations show that, in the 661 villages with illness history from the 100 townships of 13 districts in Chongqing City, 11.28\% (7464/ 66,162) of the children aged between 8 and 12 suffer from dental fluorosis; the stoves modified rate, qualified rate of modified stoves, and correct utilization rate of qualified modified stoves are respectively 100\%, 98.82\%, and 99.45\%; and food maize and hot pepper's drying rates are respectively $99.88 \%$ and 99.75\%. Conclusion: The result shows that the coal-burning type fluorosis prevalence in the endemic area of Chongqing City has decreased dramatically, the preventive measure is effectively implemented, and a long-term preventive mechanism has preliminarily been established.
\end{abstract}

\section{Keywords}

Coal-Burning Type Fluorosis, Current Prevalence Conditions

\section{Introduction}

Regional Fluorosis caused by coal-burning pollution ("coal-burning fluorosis" for short) is a kind of cumulative chronic poisoning suffered by people who live in the area with high content of coal-burning fluorine pollution for a long period of time and take in excessive fluorine through water, air, food, and some other media. There have been many studies about this in China, however, none of them is comprehensive enough to illustrate this issue. This article hence con- 
ducts a systematic and comprehensive investigation on the coal type fluorosis in children's dental fluorosis, the residents' usage of stoves, food fluorine, and urinary fluoride in Chongqing, China. In order to evaluate the effect of preventive and curing measures against coal-burning fluorosis in our City, the authors conducted an investigation on the current prevalence conditions of coal-burning fluorosis in our city from June 2013 to June 2015, whose results are analyzed as follows:

\section{Research Object and Method}

1) Objects:

Children aged between 8 and 12 and the households were chosen from May to August 2015 from the 661 villages that are historically prevalent with fluorosis in the 100 townships in 13 districts of Chongqing City.

2) Method

a) For Children's dental fluorosis:

The Dean's Method [1] was applied to examine the dental fluorosis conditions of all the locally-born children aged between 8 and 12, and calculate the dental fluorosis morbidity rate, dental fluorosis index, fluorotic teeth defect rate.

b) For Investigation in households:

Investigations were carried out on the utilization conditions of modified stoves and the drying conditions of food maize and hot pepper in households in the endemic area; calculations were made on the stoves modified rate, qualified rate of modified stoves, and correct utilization rate of qualified modified stoves, as well as the correctly drying rate of food maize and hot pepper.

c) For children's urinary fluorosis:

Children aged between 8 and 12 from over 3 endemic villages in every endemic county were sampled for test of their urinary fluorosis conditions, with the children selected from each village divided into 5 age groups and each age group assigned with 5 boys and 5 girls, i.e. 50 samples altogether from each village. And tests were conducted as per the National Standard (WS/T30-1996) to calculate the geometric mean and standard deviation for obtaining the urinary fluorine content of the sampled children.

d) For maize fluorine content:

10 households from over 3 endemic villages of every county were sampled to test the fluorine content in the maize according to the National Standard (GB/T5009-2003) by calculating the median and standard deviation.

e) For Fluorine content in hot pepper:

10 households from over three endemic villages of every endemic county for testing the food pepper in accordance with the National Standard (GB/T5009-2003) by calculating the median and standard deviation.

3) Statistical analysis was conducted adopting SPSS17.0 software to calculate the morbidity rate of fluorotic teeth and other indicators.

This research has been approved by department of health and family planning commission in Chongqing. We conducted this investigation according to the 
ethic guideline about the medical system study for people.

\section{Result}

\section{1) Basic conditions}

The investigations covered 661 endemic villages from 100 townships of 13 districts, where there are 399,314 households with a population of 1,425,705, of which children aged between 8 and 12 are numbered to 91,070 and the examined children are amounted to 66,162 , making an examination rate of $72.65 \%$.

\section{2) Children's dental fluorosis conditions}

Of the 66,162 examined children, 7464 were diagnosed with dental fluorosis, the detectable rate being $11.28 \%$, the dental fluorosis index being 0.14 , and the defect rate being $0.29 \%$. Of the villages surveyed, 426 have a dental fluorosis rate of $\leq 15 \%$, and 642 have a dental fluorosis rate of $\leq 15 \%$ (as detailed in Table 1).

\section{Household Investigation}

\subsection{Stove Modification}

Of the 399,314 households surveyed, 399,314 modified their stoves, reaching a modified rate of $100 \%$; 394,613 modified their stoves up to the qualification level, a qualified modification rate of $98.82 \%$; and 392,441 of the qualified households utilized the modified stoves correctly, representing a correct utilization rate of $99.45 \%$, benefiting a population of $1,425,705$ (as detailed in Table 2).

\subsection{Drying Conditions of Food Maize and Hot Pepper}

Of the 661 villages surveyed from 100 townships of 13 districts, 344 have food

Table 1. Dental fluorosis examination result for children aged between 8 and 12 in the endemic counties of Chongqing City prevalent with coal-burning fluorosis in Chongqing City.

\begin{tabular}{cccccccccc}
\hline $\begin{array}{c}\text { County } \\
\text { Name }\end{array}$ & $\begin{array}{c}\text { Township } \\
\text { No. }\end{array}$ & $\begin{array}{c}\text { Village } \\
\text { No. }\end{array}$ & $\begin{array}{c}\text { Children } \\
\text { Sampled }\end{array}$ & $\begin{array}{c}\text { Detected } \\
\text { No. }\end{array}$ & $\begin{array}{c}\text { Morbidity } \\
(\%)\end{array}$ & $\begin{array}{c}\text { Dental Fluorosis } \\
\text { Index }\end{array}$ & $\begin{array}{c}\text { Defect rate } \\
(\%)\end{array}$ & $\begin{array}{c}\text { Villages } \\
\leq 15 \%\end{array}$ & $\begin{array}{c}\text { Villages } \\
\leq 30 \%\end{array}$ \\
\hline Fengjie & 18 & 179 & 14,978 & 2309 & 15.42 & 0.18 & 0.50 & 93 & 179 \\
Pengshui & 16 & 86 & 10,953 & 346 & 3.16 & 0.04 & 0.22 & 85 & 86 \\
Qijiang & 3 & 19 & 1503 & 140 & 9.31 & 0.13 & 0.47 & 16 & 19 \\
Qianjiang & 16 & 74 & 11,410 & 471 & 4.13 & 0.05 & 0.16 & 68 & 73 \\
Wansheng & 2 & 14 & 1877 & 101 & 5.38 & 0.07 & 0.21 & 14 & 14 \\
Wushan & 19 & 177 & 17,410 & 3086 & 17.73 & 0.22 & 0.21 & 69 & 163 \\
Wuxi & 8 & 44 & 3182 & 532 & 16.72 & 0.25 & 0.69 & 22 & 41 \\
Yunyang & 5 & 31 & 1226 & 52 & 4.24 & 0.06 & 0.08 & 31 & 31 \\
Nanchuan & 2 & 3 & 330 & 38 & 11.52 & 0.12 & 0.00 & 2 & 3 \\
Xiushan & 3 & 8 & 399 & 49 & 12.28 & 0.15 & 0.25 & 4 & 7 \\
Shizhu & 3 & 7 & 614 & 48 & 7.82 & 0.12 & 0.16 & 7 & 7 \\
Kaixian & 2 & 12 & 1731 & 250 & 14.44 & 0.15 & 0.00 & 8 & 12 \\
Wulong & 3 & 7 & 549 & 42 & 7.65 & 0.09 & 0.00 & 7 & 7 \\
Sum & 100 & 661 & 66,162 & 7464 & 11.28 & 0.14 & 0.29 & 426 & 642 \\
\hline
\end{tabular}


Table 2. Modified stoves' examination result for endemic counties prevalent with coal-burning fluorosis in Chongqing City.

\begin{tabular}{|c|c|c|c|c|c|c|c|c|c|}
\hline $\begin{array}{l}\text { County } \\
\text { Name }\end{array}$ & $\begin{array}{l}\text { Household } \\
\text { No. }\end{array}$ & $\begin{array}{c}\text { Village } \\
\text { population }\end{array}$ & $\begin{array}{c}\text { No. of } \\
\text { Households } \\
\text { modifying } \\
\text { stoves }\end{array}$ & $\begin{array}{c}\text { Stove } \\
\text { modified } \\
\text { rate } \%\end{array}$ & $\begin{array}{c}\text { No. of } \\
\text { Households with } \\
\text { qualified modified } \\
\text { stoves }\end{array}$ & $\begin{array}{l}\text { Qualified } \\
\text { rate } \\
\text { Modified } \\
\text { stoves \% }\end{array}$ & $\begin{array}{c}\text { No. of } \\
\text { households } \\
\text { correctly } \\
\text { utilizing } \\
\text { modified stoves }\end{array}$ & $\begin{array}{c}\text { Correct } \\
\text { utilization rate } \\
\text { for stoves } \\
\text { qualifiedly } \\
\text { modified \% }\end{array}$ & $\begin{array}{c}\text { Actual } \\
\text { beneficiary } \\
\text { population }\end{array}$ \\
\hline Fengjie & 107,314 & 392,868 & 107,314 & 100 & 104,843 & 97.70 & 104,712 & 99.88 & 392,868 \\
\hline Pengshui & 48,621 & 204,844 & 48,621 & 100 & 48,474 & 99.70 & 48,454 & 99.96 & 204,844 \\
\hline Qijiang & 11,731 & 40,017 & 11,731 & 100 & 11,402 & 97.20 & 11,354 & 99.58 & 40,017 \\
\hline Qianjiang & 57,042 & 200,304 & 57,042 & 100 & 56,563 & 99.16 & 56,451 & 99.80 & 200,304 \\
\hline Wansheng & 12,697 & 44,472 & 12,697 & 100 & 12,639 & 99.54 & 12,620 & 99.85 & 44,472 \\
\hline Wushan & 102,280 & 336,299 & 102,280 & 100 & 101,614 & 99.35 & 99,849 & 98.26 & 336,299 \\
\hline Wuxi & 22,537 & 81,076 & 22,537 & 100 & 22,069 & 97.92 & 22,067 & 99.99 & 81,076 \\
\hline Yunyang & 15,382 & 49,355 & 15,382 & 100 & 15,374 & 99.95 & 15,341 & 99.79 & 49,355 \\
\hline Nanchuan & 2328 & 8875 & 2328 & 100 & 2313 & 99.36 & 2303 & 99.57 & 8875 \\
\hline Xiushan & 2190 & 8409 & 2190 & 100 & 2188 & 99.91 & 2188 & 100 & 8409 \\
\hline Shizhu & 3141 & 10,198 & 3141 & 100 & 3114 & 99.14 & 3083 & 99.00 & 10,198 \\
\hline Kaixian & 10,851 & 38,867 & 10,851 & 100 & 10,823 & 99.74 & 10,823 & 100 & 38,867 \\
\hline Wulong & 3200 & 10,121 & 3200 & 100 & 3197 & 99.91 & 3196 & 99.97 & 10,121 \\
\hline Sum & 399,314 & $1,425,705$ & 399,314 & 100 & 394,613 & 98.82 & 392,441 & 99.45 & $1,425,705$ \\
\hline
\end{tabular}

maize, and $99.88 \%$ of them correctly dried up the maize, 342 have a correct drying rate of $\geq 90 \%$, making up $99.42 \%$ of the villages with food maize, and 341 have a drying rate of $\geq 95 \%$, comprising $99.13 \%$ of the villages consuming maize. Of the villages surveyed, 657 consume edible hot pepper and $99.75 \%$ of them correctly dried the hot pepper; 655 have a correct drying rate of $\geq 90 \%$, amounting to $99.70 \%$ of the consuming villages, 655 have a correct drying of $\geq 95 \%$, amounting to $99.70 \%$ of all the consuming villages (as detailed in Table 3).

\section{Children's Urinary Fluorine Content}

The survey altogether examined 2471 urine samples from children of 52 endemic villages of 38 townships, and the result shows that the urinary fluorine's geometric mean is $0.42 \mathrm{mg} / \mathrm{L}$, standard deviation is 0.31 , the minimum value is 0.02 $\mathrm{mg} / \mathrm{L}$, and the maximum value is $2.550 .42 \mathrm{mg} / \mathrm{L}$ (as detailed in Table 4).

\section{Food Maize's Fluorine Content}

The investigation surveyed 679 food maize samples from 67 endemic villages of 46 townships, and obtained a median of $0.64 \mathrm{mg} / \mathrm{kg}$, standard deviation of 1.73 $\mathrm{mg} / \mathrm{kg}$, minimum value of $0.02 \mathrm{mg} / \mathrm{kg}$, and maximum value of $28.09 \mathrm{mg} / \mathrm{kg}$ (as detailed in Table 5).

\section{Hot Pepper's Fluorine Content}

The investigation surveyed totally 679 samples of food hot pepper from 67 en- 
Table 3. Drying conditions self-inspection result for maize and hot pepper consumed by people in the endemic counties prevalent with coal-burning fluorosis in Chongqing City.

\begin{tabular}{|c|c|c|c|c|c|c|c|c|c|c|}
\hline \multirow[b]{2}{*}{$\begin{array}{l}\text { County } \\
\text { name }\end{array}$} & \multirow[b]{2}{*}{$\begin{array}{c}\text { Township } \\
\text { NO. }\end{array}$} & \multirow[b]{2}{*}{$\begin{array}{l}\text { Village } \\
\text { No. }\end{array}$} & \multicolumn{4}{|c|}{ Drying condition of food maize } & \multicolumn{4}{|c|}{ Drying condition of food hot pepper } \\
\hline & & & $\begin{array}{l}\text { Consuming } \\
\text { village No. }\end{array}$ & $\begin{array}{c}\text { Correct } \\
\text { drying } \\
\text { rate }\end{array}$ & $\begin{array}{c}\text { No. of villages } \\
\text { whose drying } \\
\text { rate is } \geq 90 \%\end{array}$ & $\begin{array}{l}\text { No. of villages } \\
\text { whose drying } \\
\text { rate is } \geq 95 \%\end{array}$ & $\begin{array}{l}\text { Consuming } \\
\text { village No. }\end{array}$ & $\begin{array}{l}\text { Correct } \\
\text { drying } \\
\text { rate }\end{array}$ & $\begin{array}{c}\text { No. of villages } \\
\text { whose drying } \\
\text { rate is } \geq 90 \%\end{array}$ & $\begin{array}{c}\text { No. of villages } \\
\text { whose drying } \\
\text { rate is } \geq 95 \%\end{array}$ \\
\hline Fengjie & 18 & 179 & 44 & 100 & 44 & 44 & 179 & 100 & 179 & 179 \\
\hline Pengshui & 16 & 86 & 56 & 99.95 & 56 & 56 & 84 & 100 & 84 & 84 \\
\hline Qijiang & 3 & 19 & 10 & 99.57 & 10 & 10 & 19 & 98.53 & 19 & 19 \\
\hline Qianjiang & 16 & 74 & 38 & 99.00 & 36 & 35 & 72 & 98.64 & 70 & 70 \\
\hline Wansheng & 2 & 14 & 12 & 99.93 & 12 & 12 & 14 & 99.44 & 14 & 14 \\
\hline Wushan & 19 & 177 & 108 & 100 & 108 & 108 & 177 & 100 & 177 & 177 \\
\hline Wuxi & 8 & 44 & 40 & 100 & 40 & 40 & 44 & 100 & 44 & 44 \\
\hline Yunyang & 5 & 31 & 19 & 100 & 19 & 19 & 31 & 100 & 31 & 31 \\
\hline Nanchuan & 2 & 3 & 1 & 100 & 1 & 1 & 3 & 100 & 3 & 3 \\
\hline Xiushan & 3 & 8 & 4 & 100 & 4 & 4 & 8 & 100 & 8 & 8 \\
\hline Shizhu & 3 & 7 & 1 & 100 & 1 & 1 & 7 & 100 & 7 & 7 \\
\hline Kaixian & 2 & 12 & 9 & 100 & 9 & 9 & 12 & 100 & 12 & 12 \\
\hline Wulong & 3 & 7 & 2 & 100 & 2 & 2 & 7 & 100 & 7 & 7 \\
\hline Sum & 100 & 661 & 344 & 99.88 & 342 & 341 & 657 & 99.75 & 655 & 655 \\
\hline
\end{tabular}

Table 4. Children's urinary fluorine inspection result for the coal-burning endemic counties of Chongqing City.

\begin{tabular}{|c|c|c|c|c|c|c|c|}
\hline County Name & Township No. & Village No. & Sample No. & Geometric mean & Minimum value & Maximum value & Standard deviation \\
\hline Fengjie & 2 & 3 & 153 & 0.37 & 0.12 & 1.12 & 0.16 \\
\hline Pengshui & 6 & 6 & 300 & 0.40 & 0.10 & 1.34 & 0.17 \\
\hline Qijiang & 3 & 3 & 150 & 0.47 & 0.10 & 1.41 & 0.23 \\
\hline Qianjiang & 3 & 3 & 150 & 0.55 & 0.02 & 2.55 & 0.61 \\
\hline Wansheng & 2 & 3 & 150 & 0.43 & 0.10 & 1.29 & 0.18 \\
\hline Wushan & 3 & 3 & 150 & 0.54 & 0.11 & 2.20 & 0.32 \\
\hline Wuxi & 3 & 3 & 150 & 0.36 & 0.10 & 2.00 & 0.25 \\
\hline Yunyang & 3 & 3 & 150 & 0.48 & 0.08 & 2.18 & 0.36 \\
\hline Nanchuan & 2 & 3 & 154 & 0.79 & 0.26 & 1.18 & 0.24 \\
\hline Xiushan & 3 & 5 & 150 & 0.62 & 0.31 & 1.14 & 0.23 \\
\hline Shizhu & 3 & 7 & 350 & 0.37 & 0.04 & 1.94 & 0.26 \\
\hline Kaixian & 2 & 3 & 150 & 0.41 & 0.14 & 1.19 & 0.17 \\
\hline Wulong & 3 & 7 & 314 & 0.25 & 0.06 & 1.05 & 0.14 \\
\hline Sum & 38 & 52 & 2471 & 0.42 & 0.02 & 2.55 & 0.31 \\
\hline
\end{tabular}


W. Yan et al.

Table 5. Maize fluorine content inspection result for the households in endemic counties prevalent with coal-burning fluorosis in Chongqing City.

\begin{tabular}{|c|c|c|c|c|c|c|c|}
\hline County Name & Township No. & Village No. & Sample No. & Median & Minimum value & Maximum value & Standard deviation \\
\hline Fengjie & 3 & 6 & 60 & 0.80 & 0.45 & 2.90 & 0.45 \\
\hline Pengshui & 6 & 6 & 60 & 0.86 & 0.54 & 6.97 & 0.80 \\
\hline Qijiang & 3 & 3 & 30 & 0.46 & 0.31 & 0.59 & 0.08 \\
\hline Qianjiang & 3 & 3 & 30 & 1.96 & 1.27 & 2.62 & 0.29 \\
\hline Wansheng & 2 & 3 & 30 & 0.64 & 0.12 & 1.10 & 0.20 \\
\hline Wushan & 10 & 10 & 100 & 0.68 & 0.02 & 14.37 & 1.72 \\
\hline Wuxi & 3 & 3 & 31 & 0.73 & 0.58 & 1.10 & 0.11 \\
\hline Yunyang & 3 & 9 & 100 & 0.60 & 0.23 & 0.94 & 0.11 \\
\hline Nanchuan & 2 & 3 & 30 & 0.51 & 0.13 & 0.67 & 0.14 \\
\hline Xiushan & 3 & 5 & 50 & 0.41 & 0.32 & 0.80 & 0.11 \\
\hline Shizhu & 3 & 7 & 70 & 0.56 & 0.38 & 28.09 & 3.54 \\
\hline Kaixian & 2 & 3 & 30 & 0.55 & 0.47 & 0.74 & 0.06 \\
\hline Wulong & 3 & 6 & 58 & 0.71 & 0.27 & 27.84 & 3.57 \\
\hline Sum & 46 & 67 & 679 & 0.64 & 0.02 & 28.09 & 1.73 \\
\hline
\end{tabular}

Table 6. Hot pepper fluorine inspection result for households in the endemic counties prevalent with coal-burning fluorosis in Chongqing City.

\begin{tabular}{cccccccc}
\hline County name & Township No. & Village No. & Sample No. & Median & Minimum value & Maximum & Standard deviation \\
\hline Fengjie & 3 & 6 & 60 & 1.50 & 0.60 & 93.00 & 11.87 \\
Pengshui & 6 & 6 & 60 & 3.71 & 1.04 & 90.88 & 13.51 \\
Qijiang & 3 & 3 & 30 & 1.77 & 0.97 & 2.81 & 0.35 \\
Qianjiang & 3 & 3 & 30 & 2.19 & 1.49 & 15.18 & 2.77 \\
Wansheng & 2 & 3 & 30 & 3.70 & 1.10 & 100 & 23.41 \\
Wushan & 10 & 10 & 100 & 5.87 & 2.03 & 843.48 & 86.70 \\
Wuxi & 3 & 3 & 31 & 1.50 & 1.00 & 5.00 & 1.07 \\
Yunyang & 3 & 9 & 100 & 0.89 & 0.44 & 146.77 & 16.13 \\
Nanchuan & 2 & 3 & 30 & 0.44 & 0.11 & 0.80 & 0.13 \\
Xiushan & 3 & 5 & 50 & 0.76 & 0.52 & 0.98 & 0.12 \\
Shizhu & 3 & 7 & 70 & 1.54 & 0.49 & 231.21 & 28.83 \\
Kaixian & 2 & 3 & 30 & 0.75 & 0.59 & 0.87 & 0.08 \\
Wulong & 3 & 67 & 679 & 1.60 & 0.11 & 1292.20 & 61.82 \\
Sum & 46 & 6.09 & & & 171.16
\end{tabular}

demic villages of 46 townships, and obtained a median of $1.60 \mathrm{mg} / \mathrm{kg}$, standard deviation of $61.82 \mathrm{mg} / \mathrm{kg}$, minimum value of $0.11 \mathrm{mg} / \mathrm{kg}$, and maximum value of $1292.20 \mathrm{mg} / \mathrm{kg}$ (as detailed in Table 6). 


\section{Discussion}

Coal-burning type fluorosis is an endemic disease severely impacting the people's health in China, and it is a geochemical disease prevalent in China only. In addition to intake amount of pathogenic factors, the prevalence condition of a disease is also closely related with the natural environment, economic conditions, productivity and life habit [2] [3]. The pathogen of coal-burning type fluorosis in Chongqing City was brought in mainly by intake of food fluorine such as maize and hot pepper, etc. [4] in the 80s of the last century, and gradually by intake of air fluorine [5], and the total intake of fluorine through such way has seen a distinct drop [6].

This survey shows that the dental fluorosis prevalence rate for children aged between $8 \%$ and $12 \%$ is $11.28 \%$, dental fluorosis index is 0.14 , and dental defect rate is 0.29 , meaning that such prevalence belongs to a kind of negative prevalence. There are 19 villages whose dental prevalence rate is higher than $30 \%$, taking up $2.87 \%$, respectively distributing in Wushan (14), Wuxi (3), and Qianjiang (1), indicating an obvious decrease of children's dental fluorosis prevalence in our City. The investigations in the households on how they modified their stoves and how they dried up the food maize and hot pepper show that, from 2004 to 2012, with the payment transferred by central government from to local governments for prevention and treatment of endemic fluorosis for the good of public health, 282,755 households completed modifying stoves as required; and up to the end of 2015, 390,000 households of our City had completed modifying their stoves, with stoves modified rate, qualified rate of modified stoves, and correct rate for utilizing qualifiedly modified stoves respectively were $100 \%$, $99.82 \%$, and $99.45 \%$. The survey also found that drying rate of food maize and hot pepper were respectively $99.88 \%$ and $99.75 \%$. Such results showed that the prevention and curing measures have been effectively implemented and achieved sound effect. The results are consistent with other similar research results in China [7] [8].

Children's urinary fluorine is one of the important indicators for assessing fluorine content level in the human body, and in this survey, the geometric mean for children's urinary fluorine is $0.42 \pm 0.31 \mathrm{mg} / \mathrm{L}$. Of the 661 villages surveyed, 344 villages consume maize for food, accounting for $52.04 \%$ of the total villages surveyed, and maize fluorine content median is $0.64 \pm 1.73 \mathrm{mg} / \mathrm{kg}$; and 657 villages consume hot pepper for food, holding $99.39 \%$, and the median for hot pepper fluorine content is $1.60 \pm 61.82 \mathrm{mg} / \mathrm{kg}$. From these three key indicators for fluorine intake, it can be perceived that maize consuming villages are decreasing in number, and drying up maize correctly, and hot pepper consuming villages are large in number, and can basically dry up hot pepper in the correct way, which further verifies an evident drop of coal-burning type fluorosis prevalence in our City.

Investigation results demonstrate that there is clear drop of coal-burning type fluorosis prevalence in Chongqing City. the prevention and curing measures, such as adopting biomass gasifiers and fluorine-reducing smoke-recycling 
stoves, etc. have been effectively implemented and have produced distinct effects, certain achievements have been gained in terms of management of modified stoves in the post-modification period, and that a preliminary mechanism for a long-term prevention and curing of fluorosis has been established. In the future, measures will be taken in the light of the conditions of our City, and instructions will be given according to the types and categories of different endemic areas, i.e. in the endemic villages where prevention measures haven't been taken, efforts should be strengthened to implement the stove-modification measures, enhance health education, and improve hygiene behaviors; in the endemic villages where prevention measures have been adopted, work should be done for maintenance and management of modified stoves, and for reinforcing health education and intensifying good hygiene behaviors, so that the standards for eliminating fluorosis can be met; and in the endemic villages where fluorosis prevalence has been controlled, people's awareness in utilizing and purchasing modified stoves should be improved, and efforts should be made to establish such a long-term mechanism "to work on the basis of marketization, under government instruction and departmental cooperation, and with people's voluntary and positive involvement" for prevention of fluorosis prevalence, and thus maintain the status of elimination in the prevalence of fluorosis [9] [10] [11].

\section{References}

[1] The Ministry of Health of the People's Republic of China Endemic Disease Prevention and Control Department (1991) Endemic Fluorosis Prevention Manual. Chinese Endemic Disease Prevention and Control Research in the Heart, Harbin, 9-10.

[2] Li, G.S. and Ren, L.Q. (1993) Influence of Nutrition Factor on Endemic Fluorosis. Collected Papers from the Fourth Academic Conference on Endemic Diseases Held by Chinese Medical Association. Editorial Department of Chinese Journal of Endemiology, Harbin, 13-17.

[3] Liu, J.J. and Xu, H.L. (2001) Progress of Researches in Dental Fluorosis Risk Factors. Chinese Journal of Endemiology, 20, 151-153.

[4] Science Research Collaboration Team for Investigating Total Fluorine Intake (1991) Research on Total Fluorine Intake and the Fluorine Intake Ways for Coal-Burning Type Fluorosis Endemic Area. Chinese Journal of Endemiology, 10, 211-124.

[5] Yan, W., Luo, X.J., Chen, J., et al. (2009) Analysis on the Factors of Endemic Fluorosis Prevalence in Chongqing City. Modern Preventive Medicine, 36, 3006-3008, 3011.

[6] Xiao, B.Z., Chen, J., Yan, W., et al. (2009) Prevalence Factors and Preventive Measures of Coal-Burning Type Fluorosis in Chongqing City. Journal of Tropical Medicine, 9, 954-958.

[7] Chen, B.Q., Li, J.L., Wang, Y.P., et al. (1999) Prevalence Investigation for CoalBurning Type Fluorosis in Shaanxi Province. Endemic Diseases Bulletin, 14, 39-41.

[8] Li, D.S., An, D. and He, P. (2005) Investigation and Analysis on the Prevalence of Endemic Coal-Burning Type Fluorosis in Guizhou Province. Chinese Journal of Endemiology, 24, 651-654.

[9] Li, L., Liu, S.T., Wang, Y.L., et al. (2011) Research on Promotion and Application of Biomass Gasifiers in the Coal-Burning Type Fluorosis Endemic Area. Chinese 
Journal of Public Health Engineering, 10, 7-9, 11.

[10] Sun, D.J., Shen, Y.F., Zhao, X.H., et al. (2001) Trends and Status Analysis on the Prevalence of Endemic Fluorosis in Mainland China. Chinese Journal of Endemiology, 20, 429-433.

[11] Sun, Y.F. and Sun, D.J. (2004) Research Progress and Advice on Prevention and Curing of Endemic Fluorosis. Chinese Journal of Endemiology, 19, 277-280.

Submit or recommend next manuscript to SCIRP and we will provide best service for you:

Accepting pre-submission inquiries through Email, Facebook, LinkedIn, Twitter, etc. A wide selection of journals (inclusive of 9 subjects, more than 200 journals) Providing 24-hour high-quality service User-friendly online submission system Fair and swift peer-review system Efficient typesetting and proofreading procedure Display of the result of downloads and visits, as well as the number of cited articles Maximum dissemination of your research work

Submit your manuscript at: http://papersubmission.scirp.org/ Or contact ojepi@scirp.org 